\title{
KENDALI OPTIMAL PADA MODEL DINAMIK EPIDEMI DENGUE MENGGUNAKAN MISER3
}

(Optimal Control Of The Dengue Epidemic Model Using MISER3)

\author{
ZETH ARTHUR LELEURY \\ Staf Jurusan Matematika, FMIPA, Unpatti \\ Jl. Ir. M. Putuhena, Kampus Unpatti, Poka-Ambon \\ e-mail: zaleleury@yahoo.co.id / zetharthur82@gmail.com
}

\begin{abstract}
Dengue fever is an infectious tropical disease caused by the Dengue virus. Dengue haemorrhagic fever constitute a substantial health burden on world's population. In this research, an application of optimal control theory to Dengue epidemics using MISER3 was presented. The dynamic model is described by a set of nonlinear ordinary differential equations, that depend on the dynamics of the Dengue mosquito, the number of infected individuals, and people's motivation to combat the mosquito. The cost functional depends not only on the costs of medical treatment of the infected people but also on the costs related to educational and sanitation campaigns. We observe that with current computational tools it is easy to obtain, in an efficient way, better solutions to Dengue problems, leading to a decrease in the number of infected mosquitoes and individuals in less time and with lower costs.
\end{abstract}

Keywords: Dengue, Miser3, Nonlinear programming, Optimal control

\section{PENDAHULUAN}

Demam Berdarah Dengue (DBD) atau dengue haemorrhagic fever adalah penyakit virus yang ditularkan oleh nyamuk yang saat ini menjadi perhatian utama masyarakat internasional. DBD ditemukan di bagian bumi yang beriklim tropis dan sub tropis, kebanyakan di daerah kota dan daerah semi-kota. DBD pertama kali diketahui di Asia Tenggara tahun 1950an tetapi mulai tahun 1975 hingga sekarang merupakan penyebab kematian utama pada anak-anak di negara-negara Asia. Bahkan sejak tahun 1997 DBD dinyatakan sebagai penyakit asal viral terpenting yang berbahaya dan berakibat fatal bagi manusia.

DBD ditularkan pada manusia melalui gigitan nyamuk betina Aedes yang terinfeksi virus dengue. Penyakit ini tidak dapat ditularkan langsung dari orang ke orang. Penyebar utama virus dengue yaitu nyamuk Aedes aegypti, tidak ditemukan di Hong Kong, namun virus dengue juga dapat disebarkan oleh spesies lain yaitu Aedes albopictus. Menurut WHO masalah DBD tumbuh secara dramatis pada dekade terakhir ini, sekitar $40 \%$ masayarakat dunia beresiko terhadap DBD.

Berdasarkan informasi dari situs web Pusat Perlindungan Kesehatan di Indonesia, penyakit ini dilaporkan pertama kali pada tahun 1968, di kota Jakarta dan Surabaya. Epidemi penyakit DBD di luar Jawa pertama kali dilaporkan di Sumatera Barat dan Lampung tahun 1972. Sejak itu, penyakit ini semakin menyebar luas ke berbagai wilayah di Indonesia. Penularan DBD hanya dapat terjadi melalui gigitan nyamuk yang di dalam tubuhnya mengandung virus Dengue.

Hingga saat ini belum ditemukan obat khusus yang dapat membunuh virus demam berdarah, Oleh karena itu upaya pencegahan yang utama adalah menghindari gigitan nyamuk. Mengingat penyebar penyakit ini adalah nyamuk Aedes aegypti maka cara terbaik untuk memutus rantai penularan adalah dengan memberantas nyamuk tersebut, sebagaimana sering disarankan dalam sosialiasi pemberantasan penyakit DBD. Pencegahan yang murah dan efektif untuk memberantas nyamuk ini adalah dengan cara menguras tempat penampungan air bersih, bak mandi, vas bunga dan sebagainya, paling tidak seminggu sekali, mengingat nyamuk tersebut berkembang biak dari telur sampai menjadi dewasa dalam kurun waktu 7-10 hari.

Dalam penelitian ini diterapkan kendali epidemi Dengue melalui penggunaan insektisida dan sosialisasi edukasi untuk pemberantasan nyamuk yang terinfeksi Dengue. Adapun tujuan penulisan ini adalah mempresentasikan model matematika untuk mempelajari dinamika dari epidemi Dengue dengan tujuan 
meminimalkan investasi pada kendali penyakit sehingga diharapkan dapat memberikan informasi bahwa penyelesaian kendali optimal yang diperoleh dapat menjadi suatu solusi optimal dalam menentukan kebijakan untuk mencegah penyakit DBD.

Model yang digunakan didasarkan pada dinamika pertumbuhan populasi nyamuk, dan juga pada usaha manajemen masyarakat untuk memotivasi memutus siklus reproduksi nyamuk melalui pencegahan akumulasi tempat penampungan air yang terbuka dan pencegahan penyebaran daerah yang potensial untuk reproduksi nyamuk.

\section{METODE YANG DIGUNAKAN}

Penyelesaian numerik dari masalah kendali optimal secara umum dapat dikategorikan dalam dua pendekatan utama. Pendekatan pertama berhubungan dengan metode langsung yang merupakan dasar dari pendiskritan keadaan dan variabel kendali sepanjang waktu sehingga dapat digunakan software yang sesuai dengan penyelesaian permasalahan non linear programming. Pendekatan kedua berhubungan dengan pendekatan untuk metode tidak langsung dengan menggunakan persamaan keadaan, persamaan ko-keadaan, kondisi stasioner, dan kondisi batas (Subchan, 2009).

Metode yang digunakan dalam penelitian ini yaitu metode langsung (direct method). Metode langsung merupakan dasar dari transformasi masalah kendali optimal, dimana dasar diskritisasi variabel keadaan dan kendali dengan metode langsung dapat dikategorikan dalam 3 pendekatan berbeda (Subchan, 2009).

(a) Pendekatan pertama berdasarkan pada parameter keadaan dan variabel kendali. Variabel kendali dan keadaan didiskretkan dan kemudian menghasilkan diskretisasi yang diselesaikan menggunakan suatu penyelesaian pemrograman nonlinier.

(b) Pendekatan kedua adalah parameter kendali, sehingga variabel keadaan dan fungsi tujuan dapat diselesaikan oleh integrasi numerik.

Pendekatan ketiga hanya berdasarkan pada parameter keadaan.

\section{TINJAUAN PUSTAKA}

Pada bagian ini dikaji konsep teori kendali optimal dan model matematika dari epidemi Dengue. Pemodelan matematika adalah proses merumuskan abstraksi suatu sistem dalam bahasa matematika untuk mendeskripsikan dinamika yang kompleks dari suatu sistem nyata (Yang, 2008). Sedangkan model matematika adalah suatu model yang dibuat menggunakan konsep matematika seperti fungsi dan persamaan (Edwards, 1989).

\section{Teori Kendali}

Persamaan dinamik dari suatu sistem kendali adalah sebagai berikut:

$$
\dot{x}=F(x, u)
$$

dengan $x \in \mathbb{R}^{n}$ adalah variabel keadaan dan $u \in U$ adalah variabel kendali. Fungsi vektor keadaan dinyatakan sebagai berikut:

$$
\chi=\left\{x:\left[0, t_{f}\right] \rightarrow \mathbb{R}^{n} \mid x_{i} ; i=1,2, \ldots, n\right\}
$$

dan fungsi vektor kendali

$$
U=\left\{u:\left[0, t_{f}\right] \rightarrow U \subset \mathbb{R}^{m} \mid u_{i} ; i=1,2, \ldots, m\right\}
$$

dengan kendala-kendala:

$$
\begin{array}{ll}
\dot{x}=f(x(t), u(t)) & f: \mathbb{R}^{n+m} \rightarrow \mathbb{R}^{n} \\
x(0)=x_{0} \in \mathbb{R}^{n} & x_{0} \text { diketahui } \\
\psi\left(x\left(t_{f}\right), t_{f}\right)=0 \in \mathbb{R}^{p} & \psi: \mathbb{R}^{n} \mathrm{x} \mathbb{R}_{+} \rightarrow \mathbb{R}^{p}, p \leq n \\
C(x(t), u(t)) \leq 0 \in \mathbb{R}^{q} & C: \mathbb{R}^{n+m} \rightarrow \mathbb{R}^{q} \\
S(x(t)) \leq 0 \in \mathbb{R}^{s} & S: \mathbb{R}^{n} \rightarrow \mathbb{R}^{s}
\end{array}
$$

Secara umum, ada tiga bentuk fungsi tujuan (performance index) dari masalah kendali optimal, yaitu:

a. bentuk Bolza

$$
\min _{u \in U} J=\varphi\left[x\left(t_{f}\right), p, t_{f}\right]+\int_{0}^{T} V(x(t), u(t), p, t) d t
$$

b. bentuk Lagrange

$$
\min _{u \in U} J=\int_{0}^{T} V(x(t), u(t), p, t) d t
$$

$$
\begin{aligned}
& \text { c. bentuk Mayer } \\
& \qquad \min _{u \in U} J=\varphi\left[x\left(t_{f}\right), p, t_{f}\right]
\end{aligned}
$$

Indeks performa menggambarkan suatu ukuran kualitatif dari performa sistem (Subchan, 2009). Dalam penelitian ini fungsi tujuannya dinyatakan dalam bentuk Lagrange.

\section{Model Dinamik Epidemi Dengue}

Model epidemi Dengue yang dideskripsikan pada penulisan ini didasarkan pada (Caetano dkk, 2001) untuk meminimalkan Persamaan Lagrange :

$J\left(u_{1}(),. u_{2}().\right)$

$=\int_{0}^{t f}\left\{\gamma_{D} x_{3}^{2}(t)+\gamma_{F} u_{1}^{2}(t)+\gamma_{E} u_{2}^{2}(t)\right\} d t$

Dengan persamaan keadaan (state-variable) non-linier sebagai berikut:

$$
\begin{aligned}
& f=\left[\dot{x}_{i}\right]=\left[\begin{array}{llll}
f_{1} & f_{2} & f_{3} & f_{4}
\end{array}\right] \\
& \dot{x}_{1}(t)=\left[\alpha_{R}(1-\mu \sin (\omega t+\varphi))-\alpha_{M}-x_{4}(t)\right] x_{1}(t) \\
& -u_{1}(t) \\
& \dot{x}_{2}(t)=\left[\alpha_{R}(1-\mu \sin (\omega t+\varphi))-\alpha_{M}-x_{4}(t)\right] x_{2}(t) \\
& +\beta\left[x_{1}(t)-x_{2}(t)\right] x_{3}(t)-u_{1}(t) \\
& \dot{x}_{3}(t)=-\eta x_{3}(t)+\rho x_{2}(t)\left[P-x_{3}(t)\right] \\
& \dot{x}_{4}(t)=-\tau x_{4}(t)+\theta x_{3}(t)+u_{2}(t) \\
& \text { dengan } \dot{x}_{i}(t)=\frac{d x_{i}(t)}{d t}, i=1, \ldots, 4
\end{aligned}
$$

\section{Variabel state:}

$x_{1}(t)$ adalah kepadatan nyamuk

$x_{2}(t)$ adalah populasi nyamuk pembawa virus

$x_{3}(t)$ adalah jumlah individu terinfeksi 
$x_{4}(t)$ adalah tingkat motivasi untuk memberantas nyamuk (goodwill)

\section{Variabel kendali:}

$u_{1}(t)$ adalah investasi pada penggunaan insektisida

$u_{2}(t)$ adalah investasi pada sosialisasi edukasi

\section{Parameter:}

$\alpha_{R}$ : rata-rata laju reproduksi nyamuk

$\alpha_{M}$ : laju kematian nyamuk

$\beta$ : probabilitas kontak antara nyamuk pembawa virus dan individu terinfeksi

$\eta \quad$ : laju treatment dari individu terinfeksi

$\mu$ : amplitudo osilasi musiman laju reproduksi nyamuk

$\rho \quad$ : probabilitas individu yang menjadi terinfeksi

$\theta$ : faktor kekhawatiran yang merefleksikan peningkatan keinginan populasi untuk memberantas nyamuk sebagai konsekuensi prevalensi yang tinggi dari penyakit di lingkungan sosial tertentu

$\tau$ : laju forgetting untuk goodwill dari populasi target

$\varphi \quad$ : sudut fase untuk menyesuaikan musim puncak nyamuk

$\omega$ : frekuensi angular dari siklus proliferasi nyamuk, selama periode 52 minggu

$\mathrm{P} \quad$ : adalah populasi di daerah beresiko (biasanya normal untuk $P=1$ )

$\gamma_{D}$ : adalah biaya untuk keberadaan individu terinfeksi

$\gamma_{F}:$ adalah biaya setiap operasi penyemprotan insektisida

$\gamma_{E}:$ adalah biaya terkait dengan sosialiasi instruktif

Persamaan (2) merepresentasikan variasi dari kepadatan nyamuk per satuan waktu dengan siklus alami reproduksi dan kematian $\left(\alpha_{R}\right.$ dan $\left.\alpha_{M}\right)$ yang berhubungan dengan efek musim $\mu \sin (\omega t+\varphi)$ dan interferensi manusia $-x_{4}(t)$ dan $u_{1}(t)$.

Persamaan (3) mengekspresikan variasi kepadatan nyamuk yang membawa virus. Suku $\left[\alpha_{R}(1-\right.$ $\left.\mu \sin (\omega t+\varphi))-\alpha_{M}-x_{4}(t)\right] x_{2}(t)$ merepresentasikan laju infeksi nyamuk dan $\beta\left[x_{1}(t)-x_{2}(t)\right] x_{3}(t)$ merepresentasikan laju peningkatan populasi nyamuk yang terinfeksi yang nantinya memungkinkan kontak antara nyamuk yang tidak terinfeksi $x_{1}(t)-x_{2}(t)$ dan individu terinfeksi yaitu $x_{3}(t)$.

Persamaan (4) merupakan dinamika transmisi penyebaran. Suku $-\eta x_{3}(t)$ merepresentasikan laju sembuh dan $\rho x_{2}(t)\left[P-x_{3}(t)\right]$ merepresentasikan laju penyebaran kasus baru. Faktor $\left[P-x_{3}(t)\right]$ adalah jumlah individu pada area tersebut yang tidak terinfeksi.

Persamaan (5) adalah model untuk tingkat motivasi popular (goodwill) untuk memberantas siklus reproduksi nyamuk. Sebagai konsekuensinya, dibutuhkan biaya sosialisasi edukasi yang didesain untuk meningkatkan kesadaran populasi. Suku $-\tau x_{4}(t)$ menunjukkan turunnya motivasi masyarakat terhadap waktu sehingga lupa. Suku $\theta x_{3}(t)$ mereprsentasikan kesadaran alami masyarakat untuk meningkatkan prevalensi (kelaziman) penyakit.
Tujuan dari model dinamik ini adalah meminimalkan fungsional biaya persamaan (1). Fungsional ini termasuk biaya sosial yang berhubungan dengan keberadaan individu yang sakit, $\gamma_{D} x_{3}^{2}(t)$ dan kebutuhan sumber daya untuk menyebarkan insektisida, $\gamma_{F} u_{1}^{2}(t)$ dan sosialisasi edukasi, $\gamma_{E} u_{2}^{2}(t)$.

\section{HASIL DAN PEMBAHASAN}

Pembahasan hasil penelitian berupa simulasi numerik dan analisis hasil simulasi. Simulasi dari model matematika epidemi Dengue diselesaikan dengan menggunakan program MISER3 yaitu suatu toolbox matlab untuk optimisasi dinamik (Jennings dkk, 2002). Sebelum melakukan simulasi terlebih dahulu ditentukan turunan dari persamaan keadaan dan persamaan Lagrange, baik terhadap semua variabel $x$ maupun terhadap variabel kendali.

Turunan dari persamaan keadaan terhadap semua variabel $x$ :

$$
\begin{aligned}
& \frac{d f_{1}}{d x_{1}}=\alpha_{R}(1-\mu \sin (\omega t+\varphi))-\alpha_{M}-x_{4}(t) \\
& \frac{d f_{1}}{d x_{2}}=\frac{d f_{1}}{d x_{3}}=0 \\
& \frac{d f_{1}}{d x_{4}}=-x_{1}(t) \\
& \frac{d f_{2}}{d x_{1}}=\beta x_{3}(t) \\
& \frac{d f_{2}}{d x_{2}}=\alpha_{R}(1-\mu \sin (\omega t+\varphi))-\alpha_{M}-x_{4}(t) \\
& \frac{d f_{2}}{d x_{3}}=-\beta x_{2}(t), \quad \frac{d f_{2}}{d x_{4}}=-x_{2}(t) \\
& \frac{d f_{3}}{d x_{1}}=\frac{d f_{3}}{d x_{4}}=0 \\
& \frac{d f_{3}}{d x_{2}}=\rho\left(P-x_{3}(t)\right), \quad \frac{d f_{3}}{d x_{3}}=-\left(\eta+\rho x_{2}(t)\right) \\
& \frac{d f_{4}}{d x_{1}}=\frac{d f_{4}}{d x_{2}}=0 \\
& \frac{d f_{4}}{d x_{3}}=\theta, \frac{d f_{4}}{d x_{4}}=-\tau
\end{aligned}
$$

Turunan dari persamaan keadaan terhadap variabel kendali $u_{1}$ dan $u_{2}$ :

$$
\begin{array}{ll}
\frac{d f_{1}}{d u_{1}}=-1, & \frac{d f_{1}}{d u_{2}}=0 \\
\frac{d f_{2}}{d u_{1}}=-1, & \frac{d f_{2}}{d u_{2}}=0 \\
\frac{d f_{3}}{d u_{1}}=0, & \frac{d f_{3}}{d u_{2}}=0 \\
\frac{d f_{4}}{d u_{1}}=0, & \frac{d f_{4}}{d u_{2}}=1
\end{array}
$$

Turunan dari persamaan Lagrange terhadap semua variabel $x$ :

$$
\frac{d J}{d x_{1}}=0, \quad \frac{d J}{d x_{2}}=0,
$$




$$
\frac{d J}{d x_{3}}=2 \gamma_{D} x_{3}, \quad \frac{d J}{d x_{4}}=0
$$

Turunan dari persamaan Lagrange terhadap kendali $u_{1}$ dan $u_{2}$ :

$$
\frac{d J}{d u_{1}}=2 \gamma_{F} u_{1}, \quad \frac{d J}{d u_{2}}=2 \gamma_{E} u_{2}
$$

Hasil simulasi ini bertujuan untuk mendapatkan nilai optimasi secara numerik dari fungsi kendali yang mengindikasikan investasi pada penggunaan insektisida dan sosialisasi edukasi, dengan menggunakan estimasi nilai parameter yang ternormalisasi pada tabel di bawah ini (Helena dkk, 2010).

$$
\begin{array}{lll}
\alpha_{R}=0.20 & \tau=0.1 & x_{1}(0)=1.0 \\
\alpha_{M}=0.18 & \varphi=0 & x_{2}(0)=0.12 \\
\beta=0.3 & \omega=\frac{2 \pi}{52} & x_{3}(0)=0.004 \\
& P=1.0 \mathrm{P} & x_{4}(0)=0.05 \\
\mu=0.15 & \gamma_{D}=1.0 & \\
\rho=0.1 & \gamma_{F}=0.8 & \\
\theta=0.05 & \gamma_{E}=0.8 &
\end{array}
$$

Dengan mensubtitusikan nilai-nilai numerik yang diberikan di atas maka model dinamik epidemi Dengue persamaan (1)-(5) menjadi:

$$
\begin{aligned}
& J\left(u_{1}(.), u_{2}(.)\right) \\
& =\int_{0}^{t f}\left\{x_{3}^{2}(t)+0.4 u_{1}^{2}(t)+0.8 u_{2}^{2}(t)\right\} d t
\end{aligned}
$$

Dengan variabel state sebagai berikut:

$$
\begin{aligned}
\dot{x}_{1}(t)= & {\left[0.2-0.02 \sin \left(\frac{2 \pi}{52} t\right)-0.18-x_{4}(t)\right] x_{1}(t) } \\
& -u_{1}(t) \\
\dot{x}_{2}(t)= & {\left[0.2-0.02 \sin \left(\frac{2 \pi}{52} t\right)-0.18-x_{4}(t)\right] x_{2}(t) } \\
& +\left[0.3 x_{1}(t)+0.3 x_{2}(t)\right] x_{3}(t)-u_{1}(t) \\
\dot{x}_{3}(t)=- & 0.15 x_{3}(t)+0.1 x_{2}(t)-0.1 x_{2}(t) x_{3}(t) \\
\dot{x}_{4}(t)= & \left.-0.1 x_{4}(t)+0.05 x_{3}(t)+u_{2}(t)\right]
\end{aligned}
$$

Proses simulasi dilakukan dengan waktu awal $t_{0}=0$ dan waktu akhir tetap $t_{f}=52$ minggu.

Pada gambar (1)-(6) berikut menunjukan trayektori variabel state dan variabel kendali dari hasil simulasi model dinamik epidemi Dengue dengan kendali yang dikenakan pada suatu fungsi objektif untuk meminimalkan fungsional biaya terkait dengan biaya sosial yang berhubungan dengan keberadaan individu yang sakit, kebutuhan sumber daya untuk menyebarkan insektisida, serta sosialisasi edukasi,

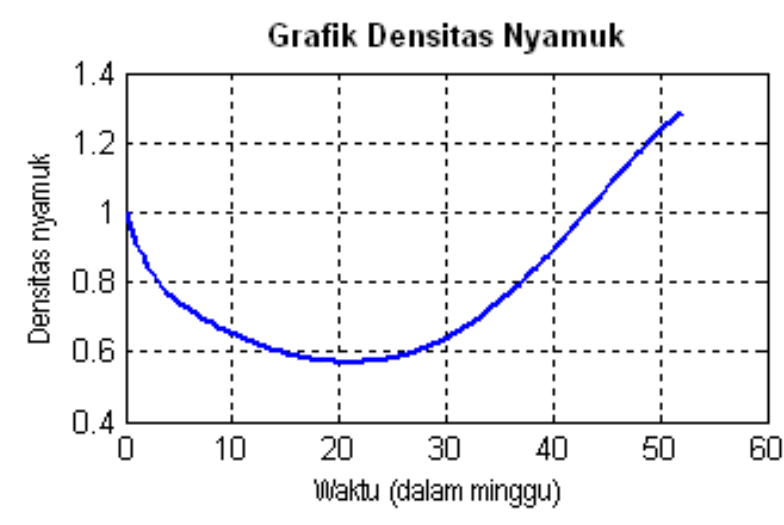

Gambar 1. Grafik Populasi Kepadatan Nyamuk

Grafik Populasi Nyamuk Terinfeksi

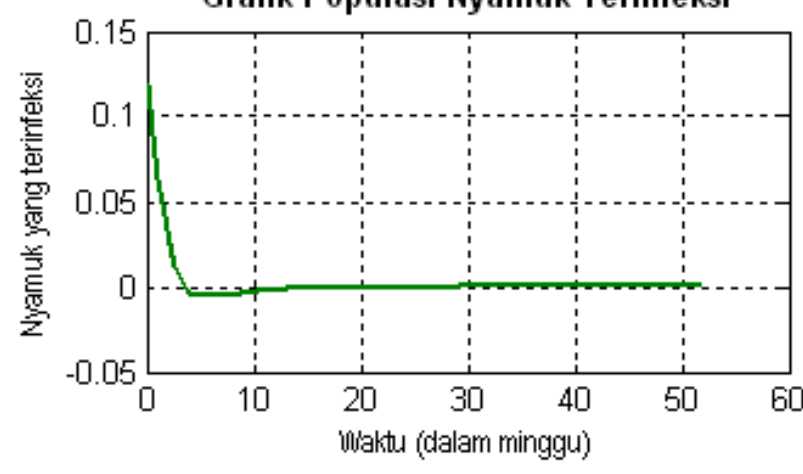

Gambar 2. Grafik Populasi Nyamuk Terinfeksi

Dari Gambar 1 di atas dapat disimpulkan bahwa trayektori kepadatan nyamuk mengalami osilasi dan akan naik lagi pada minggu ke-23. Namun trayektori populasi nyamuk yang terinfeksi akan menurun atau berkurang drastis bahkan setelah 4 minggu pertama populasi nyamuk yang terinfeksi berada pada nilai nol seperti terlihata pada Gambar 2.

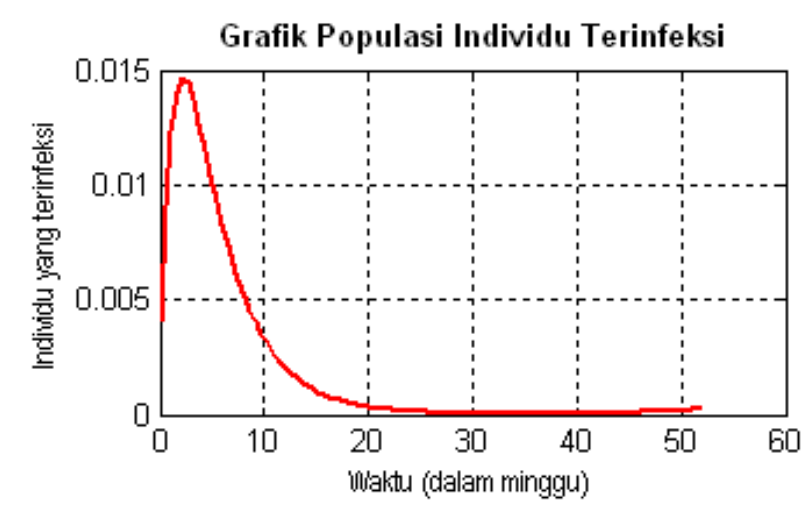

Gambar 3. Grafik Populasi Individu yang Terinfeksi

Selanjutnya dari Gambar 3 menunjukkan bahwa trayektori jumlah individu yang terinfeksi akan menurun drastitis pada saat minggu ke-3 hingga minggu ke-25 dan setelah $t>25$ minggu trayektori sudah berada pada titik nol. Hal ini seiring dengan berkurangnya populasi nyamuk yang terinfeksi. 
Dengan demikian, maka tingkat motivasi yang popular (seperti pencegahan tempat penampungan air yang terbuka) terus menurun dari minggu ke minggu seperti yang ditunjukkan pada Gambar 4.

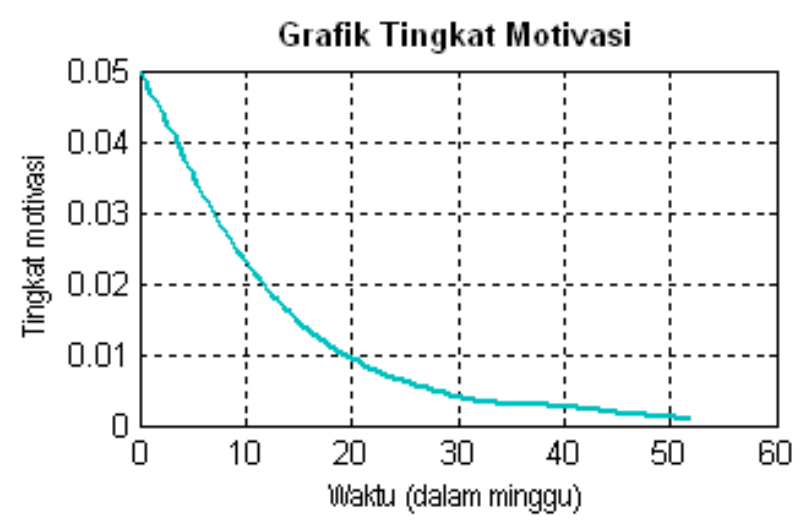

Gambar 4. Grafik Tingkat Motivasi untuk Memberantas Nyamuk

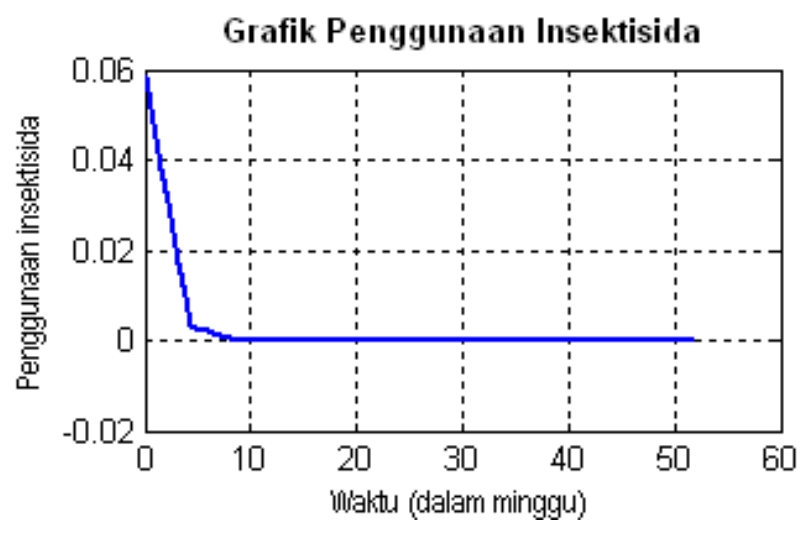

Gambar 5. Grafik Investasi Pada Penggunaan Inseksitida

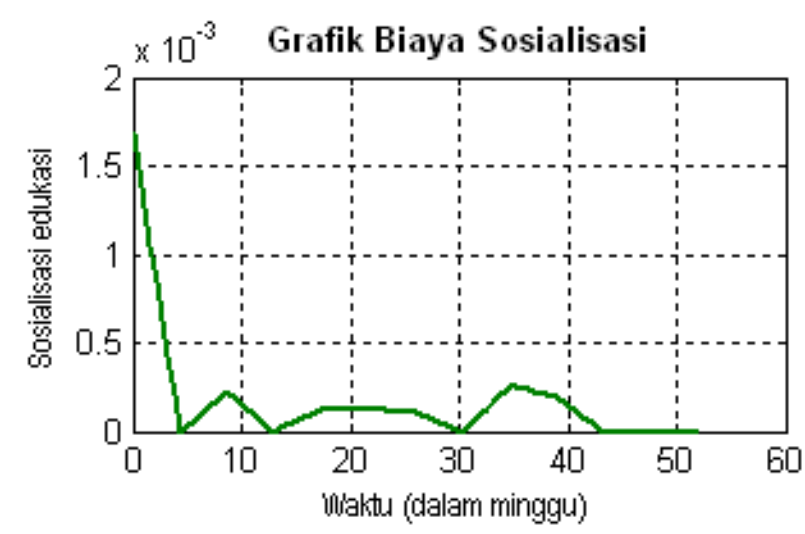

Gambar 6. Grafik Investasi Pada Sosialisasi Edukasi

Dari Gambar 5 menunjukkan bahwa penggunaan insektisida berpengaruh tinggi pada minggu pertama dan akan berkurang pengaruhnya hingga pada minggu ke-9. Sedangkan berdasarkan pada Gambar 6 disimpulkan bahwa pengaruh sosialisasi edukasi belum dapat memberikan kendali yang terbaik karena terlihat adanya dinamika yang tidak menentu dan tidak teratur dari minggu ke minggu sejak minggu keempat.

\section{KESIMPULAN}

Dari pembahasan pada bagian sebelumnya, maka dapat disimpulkan bahwa penggunaan insektisida lebih banyak berpengaruh terhadap penurunan populasi nyamuk maupun individu yang terinfeksi virus Dengue dibandingkan dengan sosialisasi edukasi. Akan tetapi untuk memperoleh hasil yang optimal maka upaya yang dapat dilakukan adalah dengan melakukan penyebaran insektisida dan sosialisasi edukasi secara bersama-sama.

Hasil yang diperoleh akan dapat digunakan untuk menentukan kebijakan terbaik sebelum melakukan operasi di lapangan. Otoritas kesehatan seharusnya diberi perhatian yang lebih awal untuk masalah epidemologi contohnya pada keputusan kendali yang efektik pada empat minggu pertama mempunyai aturan yang pasti untuk melawan DBD, masyarakat dan pemerintah akan mendapatkan keuntungan dari pengambilan keputusan tersebut.

\section{DAFTAR PUSTAKA}

Caetano, M.A.L., Yoneyama, T, Optimal and sub-optimal control in Dengue epidemics, Optimal Control Applications and Methods 22 (2001) 63_73.

Edwards, D., Hamson, M. Guide to mathematical Modelling, The Macmillan Press, Ltd. (1989)

Hadi, U.K, Penyakit Tular Vektor Demam Berdarah Dengue. IPB, Bogor.

Helena, S.R., Teresa, M.M., Delfim, F.M.T, Dynamics of dengue epidemis when using optimal control, Mathematical and Computer Modelling 52 (2010) 1667-1673

Jennings, L.S., Fisher, M.E., Teo, K.L, Goh., C.G, MISER3, Optimal Control Software : Theory and User Manual Version 2.0 (2002).

Subchan, S., Zbikowski, R., Computational Optimal Control Tools and Practise, John Willey and Sons, Ltd, publication, United Kingdom. (2009).

Yang, S.X, Mathematical Modelling for Earth Sciences, Dunedin Academic Press, Ltd, Scotland. (2008), www.chp.gov.hk Situs web Pusat Perlindungan Kesehatan: 